\title{
Insect (Hexapoda) diversity in the Oceanic Archipelago of Fernando de Noronha, Brazil: Seasonality and Populational Density of Tabanidae (Diptera)
}

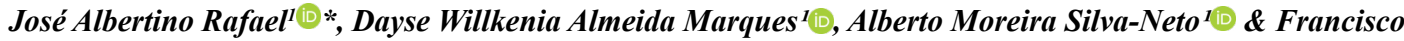 \\ Limeira-de-Oliveira ${ }^{2}$

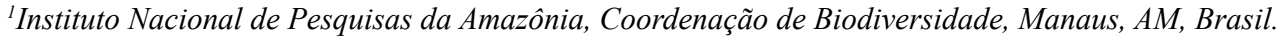 \\ ${ }_{2}^{2}$ Universidade Estadual do Maranhão, Centro de Estudos Superiores de Caxias, Caxias, MA, Brasil. \\ *Corresponding author: jarafael@inpa.gov.br
}

RAFAEL, J.A., MARQUES, D.W.A., SILVA-NETO, A.M., LIMEIRA-DE-OLIVEIRA, F. Insect (Hexapoda) diversity in the Oceanic Archipelago of Fernando de Noronha, Brazil: Seasonality and Populational Density of Tabanidae (Diptera). Biota Neotropica 21(3): e20211211. https://doi.org/10.1590/1676-0611-BN-2021-1211

\begin{abstract}
The seasonal population density is informed for two epidemiologically important species of bloodsucking Tabanidae, Tabanus occidentalis Linnaeus and T. pungens Wiedemann, recorded at the Fernando de Noronha archipelago that was never connected to the continent. The two species are widespread in the Neotropical Region, have not been recorded from any other oceanic island, and have most likely been introduced accidentally in the archipelago. Tabanus occidentalis dominated the samples, encompassing $99.6 \%$ of the specimens collected in the two local seasons, rainy and dry. Tabanus pungens was rarer, encompassing $0.4 \%$ of the specimens collected mainly in the dry season. The tabanids of Fernando de Noronha are able to transmit blood pathogens, bringing risks to the health of the livestock. They also pester the tourists, which brings losses to the local tourist industry. Larvae of both species were already collected in the water lettuce Pistia stratiotes Linnaeus and it is highly recommend that this introduced aquatic plant be removed from the ponds of Fernando de Noronha to control tabanid populations. Keywords: Fernando de Noronha archipelago; horse flies; neotropics; oceanic islands fauna; Tabanus.
\end{abstract}

\section{Diversidade de insetos (Hexapoda) no Arquipélago Oceânico de Fernando de Noronha, Brasil: Sazonalidade e Densidade Populacional de Tabanidae (Diptera)}

\begin{abstract}
Resumo: A densidade populacional e a sazonalidade é informada para duas espécies epidemiologicamente importantes de Tabanidae, Tabanus occidentalis Linnaeus e T. pungens Wiedemann, registradas no arquipélago de Fernando de Noronha, o qual nunca foi conectado ao continente. As duas espécies estão amplamente distribuídas na Região Neotropical, não foram registradas em nenhuma outra ilha oceânica e provavelmente foram introduzidas acidentalmente no arquipélago. Tabanus occidentalis dominou as amostras, englobando 99,6\% dos exemplares coletados nas duas estações locais, chuvosa e seca. Tabanus pungens foi mais rara, abrangendo $0,4 \%$ dos espécimes coletados principalmente na estação seca. Os tabanídeos de Fernando de Noronha são capazes de transmitir patógenos do sangue, trazendo riscos à saúde do gado. Eles também incomodam os turistas, o que traz prejuízos para a indústria turística local. Larvas de ambas as espécies já foram coletadas na alface d'água Pistia stratiotes Linnaeus e é altamente recomendável que esta planta aquática, introduzida no arquipélago, seja removida das lagoas de Fernando de Noronha para o controle de populações de tabanídeos.
\end{abstract}

Palavras-chave: mutucas; Neotrópico; fauna de ilhas oceânicas; Tabanus. 


\section{Introduction}

The Brazilian oceanic archipelago of Fernando de Noronha is located at the equatorial South Atlantic region (Figure 1). It is under the jurisdiction of the state of Pernambuco, but it is also a federal preservation area (i.e., National Park) managed by Instituto Chico Mendes de Conservação da Biodiversidade - ICMBio (agency of the Brazilian Ministry of Environment) (Rafael et al. 2020). Fernando de Noronha is located c. $360 \mathrm{~km}$ from the nearest continental Brazilian coast in the state of Rio Grande do Norte (Figure 1). The archipelago represents the top of a volcanic cone belonging to an underwater mountain. This mountain is estimated at 12.0 to 1.5 million years old and has never been connected to the mainland (Barcellos et al. 2015). In total, the archipelago has 21 islands, encompassing $18.4 \mathrm{~km}^{2}$. The only island inhabited by humans is the main island, Fernando de Noronha, encompassing $16.9 \mathrm{~km}^{2}$ (Teixeira et al. 2003, Rafael et al. 2020).

Fernando de Noronha is the most intensively studied Brazilian oceanic island. Its marine biota, terrestrial vertebrates and plants have received especial attention. The archipelago's biota has suffered major ecological perturbations from several invasive animal and plant species that have been introduced to the islands (Teixeira et al. 2003). Tourism is now a major economic activity and the archipelago faces challenges to minimize anthropogenic impacts on its biota, prompting the need for inventories.

There are only a few studies on the insects of the Fernando de Noronha archipelago and the publication records for all groups of insects occurring there were summarized by Rafael et al. (2020). The first flies recorded from the archipelago were one species each in Dolichopodidae, Sarcophagidae and Syrphidae (Kirby 1890). Seventytwo years later, Alvarenga (1962) recorded two species in Culicidae and one in Calliphoridae, followed by Couri et al. (2008), who recorded three species in Sarcophagidae, two in Calliphoridae, one in Fanniidae, six in Muscidae and four morphospecies based on unidentified specimens of Sepsidae, Stratiomyidae, Tabanidae and Ulidiidae, the last as Otitidae. Over the last 12 years the largest amount of information was generated. Cordeiro et al. (2008) added one species of Culicidae; Oliveira et al. $(2009,2010)$ added seven species of Drosophilidae and Carmo \& Vasconcelos (2014) added one species of Calliphoridae, totaling 31 species of Diptera. The last paper was published recently treating all groups of insects and increasing the number of Diptera to 134 species/ morphospecies (Rafael et al. 2020).

The first record of Tabanidae in Fernando de Noronha was made by Couri et al. (2008) based on one unidentified specimen. Only recently two species were identified, Tabanus occidentalis Linnaeus, 1758 and T. pungens Wiedemann, 1828 (Rafael et al. 2020) based on a large series of specimens collected during nine months using interception traps and animal bait.

The presence of tabanids pests poses an important problem to livestock, local residents and the tourist industry, particularly when the tourists are attacked by tabanids when they are trying to enjoy the beach. This study aims to gain a better understanding of the seasonality, density, and habitat of this epidemiologically important group of insects.

\section{Materials and Methods}

The Fernando de Noronha archipelago (latitude $3^{\circ} 45^{\prime} \mathrm{S}$ to $3^{\circ} 57^{\prime} \mathrm{S}$; longitude $32^{\circ} 19^{\prime} \mathrm{W}$ to $32^{\circ} 41^{\prime} \mathrm{W}$ ) (Figure 1) is of volcanic origin and was never connected to the continent. It has a tropical oceanic climate (Awi - Köppen classification). The temperature ranges from $23.5^{\circ} \mathrm{C}$
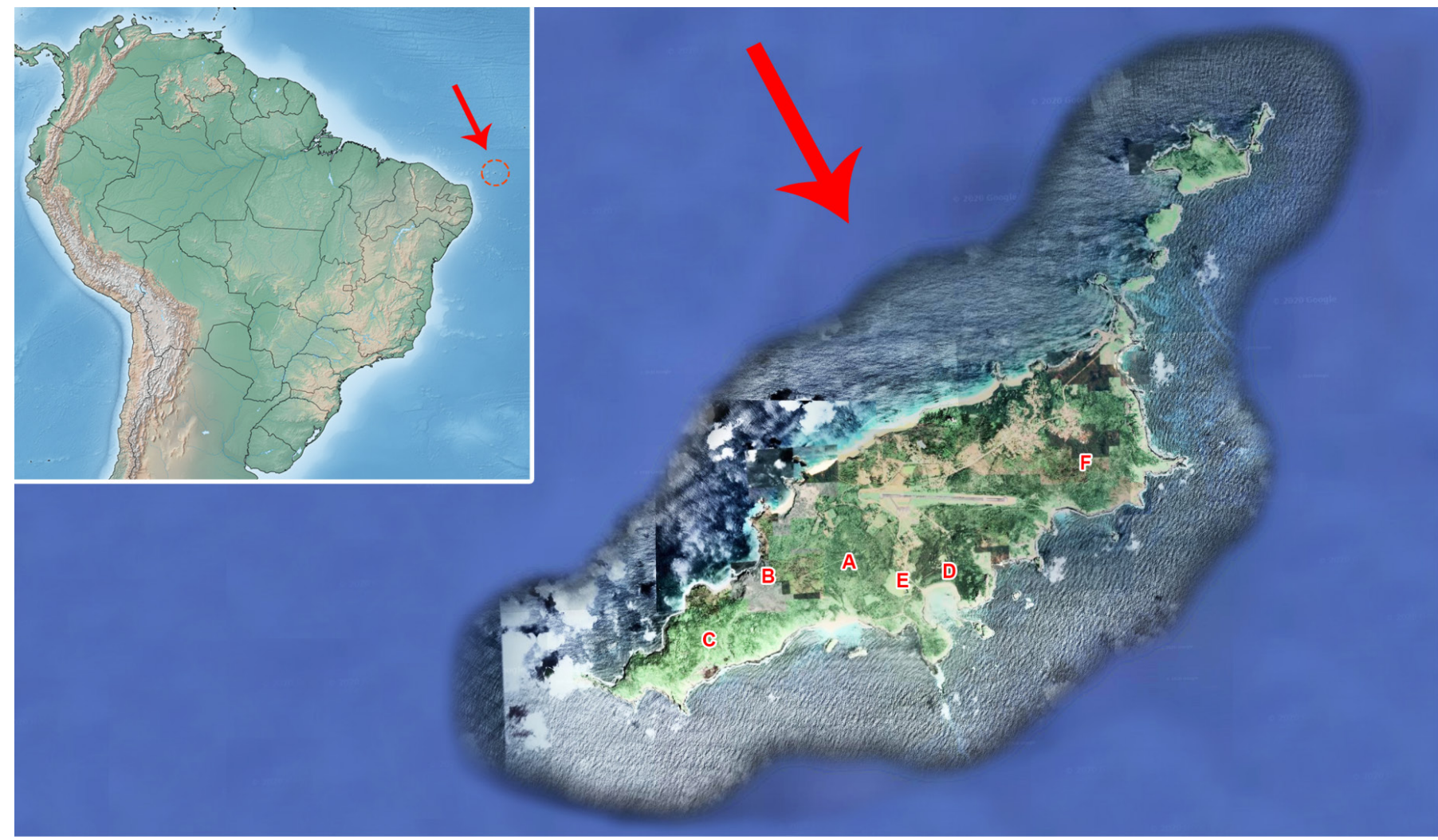

Figure 1. Location of the Archipelago Fernando de Noronha and points of Tabanidae collections: A) Sancho-Dolphins bay trail; B) Dolphins bay lookout; C) CapimAçú trail; D) Mangrove; E) Xaréu pond; F) Atalaia trail. 
to $31.5^{\circ} \mathrm{C}$, with an annual mean of $28^{\circ} \mathrm{C}$ (IBAMA 2006) and annual precipitation of $1,400 \mathrm{~mm}$, but with large interannual variability. It is characterized by a dry season, with a mean precipitation of $27.2 \mathrm{~mm} /$ month (August-January), and a rainy season, with a mean precipitation of $211.7 \mathrm{~mm} / \mathrm{month}$ (March-July). The climatic regimes of Fernando de Noronha are similar to the semi-arid region of the Brazilian Northeast. There, most of the rain is concentrated in a period of three to four months. The archipelago has a harsh environment, lacking a permanent source of freshwater, with low vegetation diversity and a shallow soil that has little capacity for water retention (Freitas et al. 2013, Rafael et al. 2020).

The specimens collected during this survey will be distributed among main Brazilian collections, namely: INPA, Instituto Nacional de Pesquisas da Amazônia, Manaus, Amazonas; CZMA, Coleção Zoológica do Maranhão, Caxias, Maranhão; DZUP, Coleção Entomológica Padre Jesus Santiago Moure, Departamento de Zoologia, Universidade Federal do Paraná, Curitiba, Paraná; MNRJ, Museu Nacional, Universidade Federal do Rio de Janeiro, Rio de Janeiro, Rio de Janeiro; MPEG, Museu Paraense Emílio Goeldi, Belém, Pará and MZUSP, Museu de Zoologia da Universidade de São Paulo, São Paulo, São Paulo.
The collecting license number for this project is 62.821 , issued by Instituto Chico Mendes de Conservação da Biodiversidade (ICMBio).

Three sites on the main island Fernando de Noronha (Figure 1) were selected for continuous collecting (from June 9, 2019 to February 27, 2020) using Malaise interception traps based on the following criteria: accessibility, diversity of vegetation, low degree of exposure to human activities, and geographical position inside the National Park area. Human impact on the collecting sites was categorized as minor since the three areas are only open to guided tourism, scientific and management activities. The three sites are: 1) Sancho-Dolphins bay trail, near the information and control desk (Figure 1a): two interception traps, model Townes (Townes 1972) (Figure 2a), placed 100 meters from each other; 2) next to the lookout at dolphins bay (Figure 1b): one interception trap, model Gressitt \& Gressitt (1962) (Figure 2b) and; 3) on the Capim-Açu trail (Figure 1c): one interception trap, model Gressitt \& Gressitt. The collecting activities were interrupted on March 15, as a result of the covid-19 pandemic.

Additionally, insects were sampled using Malaise interception traps from 2 to 9 June 2019 and from 20 to 27 February 2020, with additional points of collection in the following locations of the main island:
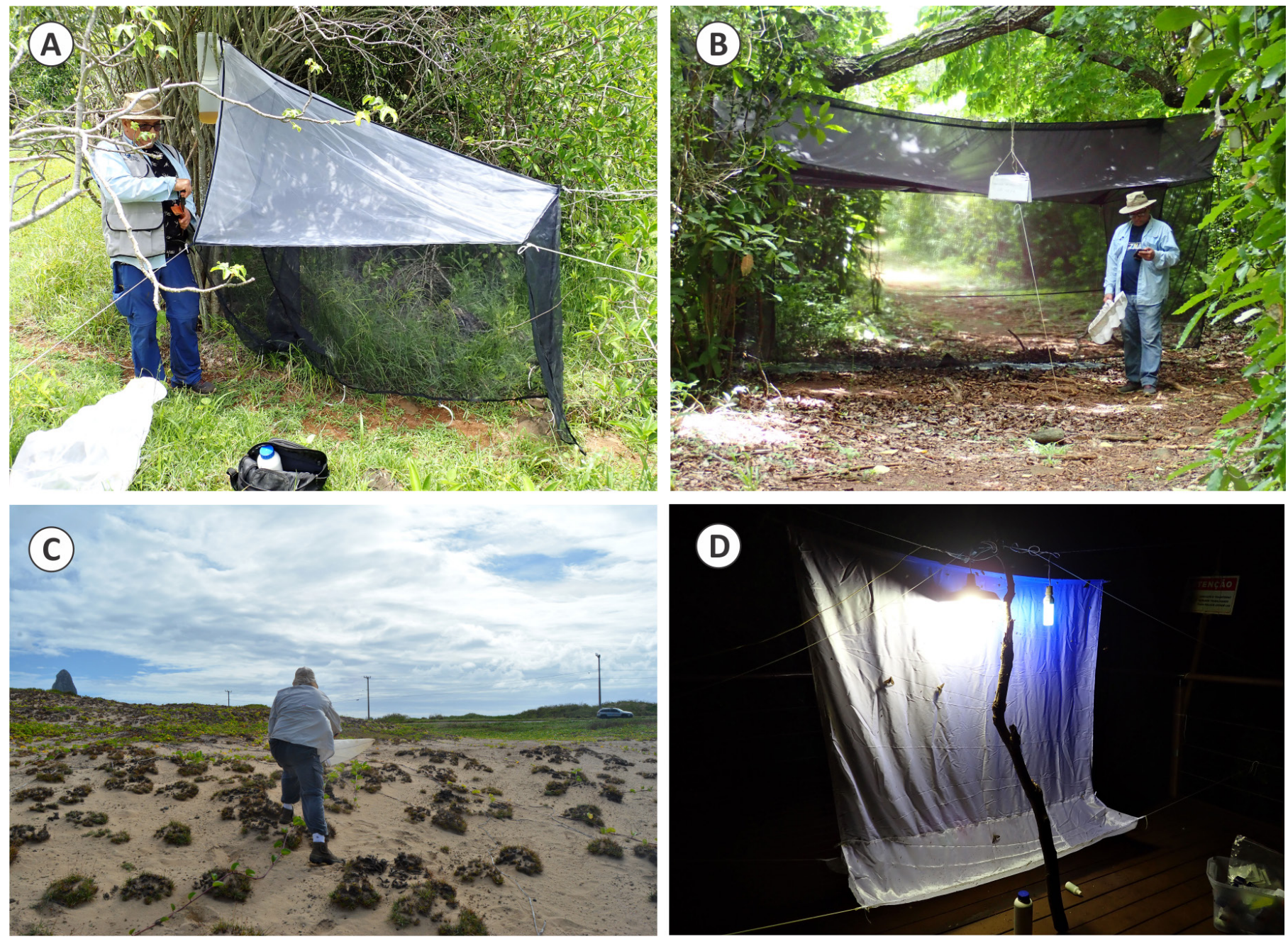

Figure 2. Collection methods: A) Malaise trap, Townes model (Atalaia trail); B) Malaise trap, Gressitt \& Gressitt model (Capim-Açú trail); C) Net sweeping over dunes (area around the Fernando de Noronha harbor); D) Light trap, UV and mercury lamps (Golfinhos trail). 
Mangrove (Figure 1d); Xaréu pond (Figure 1e) and Atalaia trail (Figure 1f). Active collecting was conducted during June and February with entomological nets (Figure 2c), light trapping using a white sheet lit by a 250-watt mercury vapor and 40-watt UV lamps (Figure 2d) and animal bait (i.e. horse) to attract hematophagous horse flies and mosquitoes.

Specimens were labelled, preserved in small containers with commercial ethanol $\left(94^{\circ}\right)$, and temporarily stored in the ICMBio laboratory in the main island. The collected material was later transported to the INPA and CZMA, where each sample was sorted, labelled, identified and quantified.

We used the software R program ( $R$ Core Team 2020) to calculate the Pearson correlation between populational density versus precipitation and temperature only for continuous collecting (from June 9, 2019 to February 27, 2020). The precipitation data was obtained from https://pt.climate-data. org/america-do-sul/brasil/pernambuco/fernando-de-noronha-1006098/ and refers to the mean monthly precipitation during 40 years (1982 to 2012) and the monthly data on tabanids refers to the two combined biweekly collections.

The distribution map was generated on the website www. simplemappr.net (Shorthouse 2010).

\section{Results}

A total of 1,653 adult horse fly specimens, distributed in two species, were collected during nine months using interception traps: 1,648 specimens were Tabanus occidentalis $(99.6 \%)$, and six were T. pungens $(0.4 \%)$.

\section{Tabanus occidentalis (Figures 3a-e)}

This species belongs to a complex of species that have been treated as "varieties" or subspecies, but presently all "varieties" or subespecies are under T. occidentalis according to the Neotropical catalogue (Coscarón \& Papavero 2009).

It is characterized by the following combination of characters: 10 $\mathrm{mm}$ from head (excluded antennae) to apex of abdomen; eye in live or relaxed specimens with green and blue iridescent bands (Figure 3c); frons (Figure 3b) slightly converging toward basal callus, about $6 \mathrm{X}$ higher than basal width (measured at ventral level of basal callus to the vertex); basal callus subrectangular, narrower than frons; antenna (Figure 3d) with basal plate produced dorsally, $1.5 \mathrm{X}$ longer than maximum height and distinctly longer than stylus (the darker terminal segments); fore leg (Figure 3e) with femur black and tibia distinctly bicolored white and black on distal half; wing (Figure 3a) hyaline with pterostigma dark brown; abdomen (Figure 3a) with both midlongitudinal and sublateral stripes of contiguous pale triangles, the mid one whitish and more conspicuous.

This species is widely spread in the Neotropical Region, from Mexico to Argentina (Entre Ríos, Buenos Aires) and in Trinidad (Coscarón \& Papavero 2009). It was recorded only recently from the Fernando de Noronha island (Rafael et al. 2020) and this is the only oceanic island where it has been recorded.

Tabanus occidentalis is the most abundant horse fly in Fernando de Noronha, representing $99.6 \%$ of the specimens collected throughout the nine months using interception traps, from June 2019 to February 2010, in both rainy and dry seasons (Figure 4).

In the six months of the dry season, from August to January (Figure 4), 968 specimens were collected using interception traps, against 685 specimens in only three months of collections during the rainy season (June, July/2019 and February/2020). The fewest number of specimens
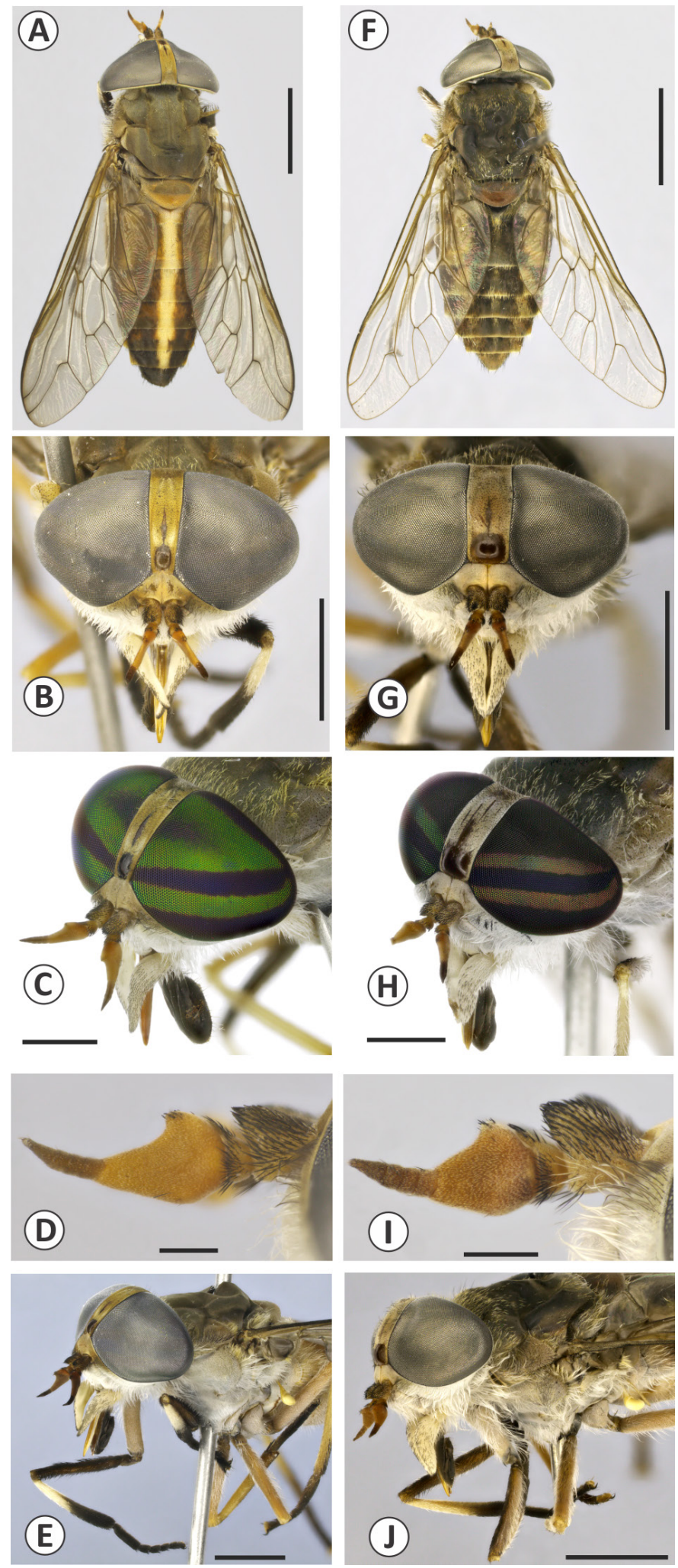

Figure 3. Morphology of Tabanus species: A-E) Tabanus occidentalis; F-J) Tabanus pungens; $\mathrm{A}$ and F), Habitus, dorsal view; $\mathrm{B}$ and $\mathrm{G}$ ) Frons, frontal view; $\mathrm{C}$ and $\mathrm{H}$ ) Head, frontolateral view; D and I) Antenna, lateral view; E and J) Head, thorax and legs, lateral view. 


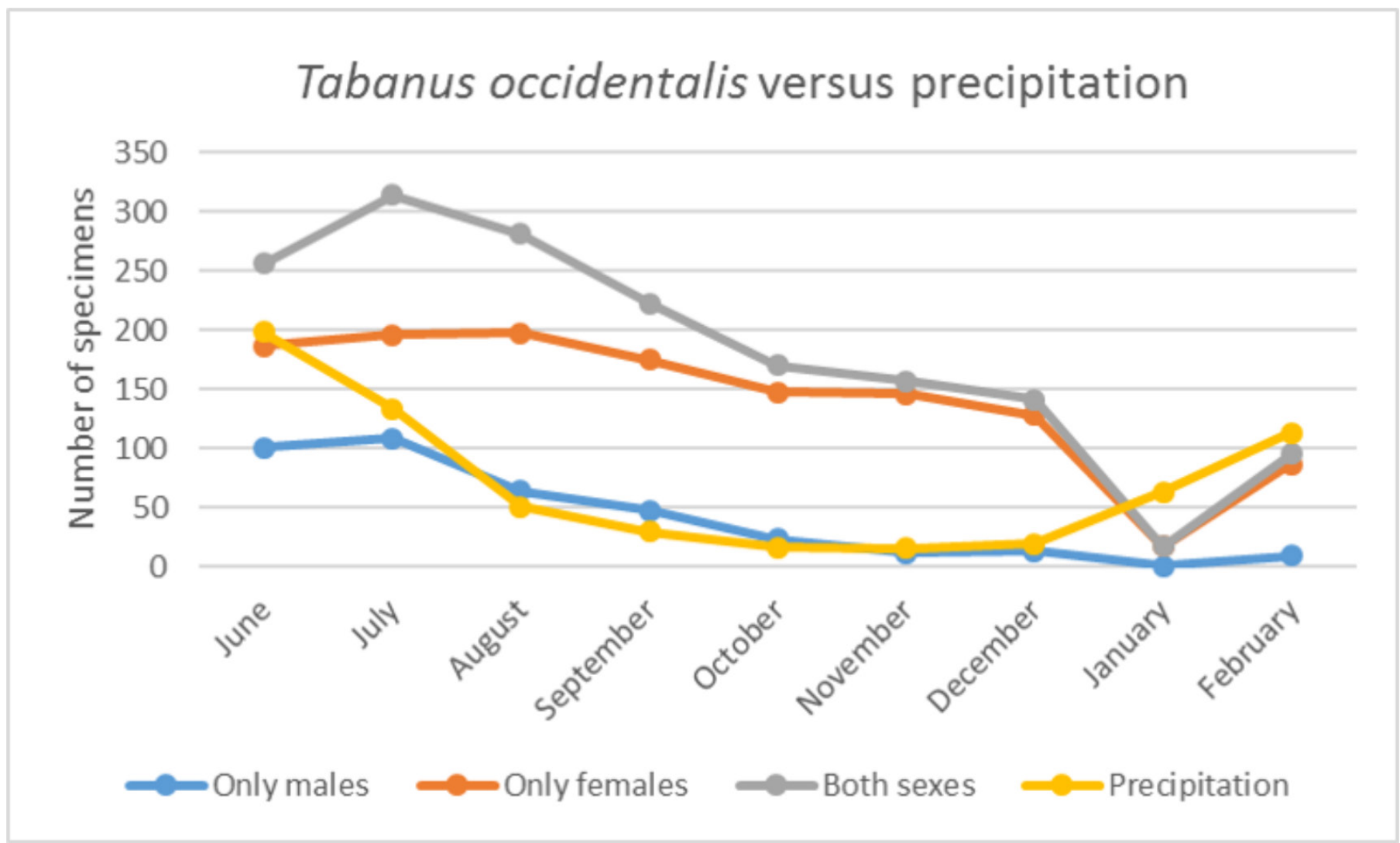

Figure 4. Tabanus occidentalis: Seasonal ocurrence of males, females and both together using interception traps in Fernando de Noronha and average of precipitation.

were collected in January, the last month of the dry season (Figure 4). Over the next month, February, first month of the rainy season, the number of tabanids specimens increased (Figure 4). The prediction is that we would find many more specimens in the following three months (March, April, May), reflecting the moderate to high positive linear relationship with precipitation. To analyze the linear relationship we considered only males, then only females, followed by males and females together.

The results for $T$. occidentalis failed to find a positive relationship between density and precipitation when considering male and female specimens together (Pearson $r=0.360, p>0.05$, non significative) or when considering only female specimens (Pearson $r=0.097, p>0.05$ ). However, when considering only male specimens, a positive linear relationship with precipitation was revealed (Pearson $r=0.683, p<0.05)$.

Concerning the temperature, there was a negative linear relationship with density for T. occidentalis (Pearson $\mathrm{r}=-0.882$, $\mathrm{p}<0.01$ ) when male and females specimens were pooled together. When both sexes are analyzed individually, a negative linear relationship with temperature was found (Pearson $\mathrm{r}=-0.987, \mathrm{p}<0.001$ ) when considering only male specimens and a non significative relationship with temperature (Pearson $r=0.097, p>0.05$ ) when considering only female specimens.

The average monthly temperature did not vary much during the year, maintaining an average of $27^{\circ} \mathrm{C}$, varying around one degree above and below.

Tabannus occidentalis was found in all three sites throughout the nine months using continuous interception traps and surprisingly with a high proportion of male specimens, 375 specimens $(22.7 \%)$. Both sexes were more abundant at Capim-Açú trail, with 1,402 specimens (84,8\%). CapimAçu is a more preserved area and the trap was mounted crossing a wide trail.
Tabanus pungens (Figures $3 \mathrm{f}-\mathrm{j}$ )

Tabanus pungens is characterized by the following combination of characters: $10 \mathrm{~mm}$ from head (excluded antennae) to apex of abdomen; eye in life or relaxed specimens with green and blue iridescent bands (Figure 3h); frons (Figure 3g) subparallel, about 2.5 to 3.0X higher than wide (measured at ventral level of basal callus to the vertex); basal callus subquadrate, slightly narrower than frons; antenna (Figure 3i) with basal plate produced dorsally, as long as maximum high and slightly longer than stylus (the darker terminal segments); fore leg (Figure 3j) with femur yellow to light brown and tibia bicolored light yellow and black at distal third; wing (Figure 3f) hyaline with pterostigma light brown; abdomen (Figure 3f) with black mid-longitudinal stripe wider than sublateral stripes of contiguous pale triangles, smaller posteriorly.

A widely distributed species occurring from Texas (USA) to entire Neotropical Region (except West Indies and Chile) and in Trinidad (Coscarón \& Papavero 2009). As the first species, it also was recorded only recently in Fernando de Noronha (Rafael et al. 2020) and this is the only oceanic island from which it has been recorded.

Tabanus pungens was collected in low density, only six specimens collected throughout the nine months using continuous interception traps. This species was collected at two sites: at Dolphins bay lookout (2 specimens in August 2019) and at Capim-Açu trail (4 specimens in July, August, September, October and November 2019).

Despite the few specimens (six), the results suggest that the relationship between the density of $T$. pungens with precipitation is linear negative $($ Pearson $\mathrm{r}=-0.748, \mathrm{p}<0.05)$ and no significant correlation was found with temperature (Pearson $r=0.207, p>0.05$ ). 
Tabanus pungens specimens were collected while biting humans, cows and horses and were more frequently found on humans. No male specimens were collected.

During a short period, eight days, one small interception trap, Townes model, was mounted at one side of the Xaréu pond and there it collected 40 female specimens of T. pungens, more than in all other traps together during nine months.

Additionally, horse bait was used trying to find more species of tabanid species in Fernando de Noronha, but only T. occidentalis and $T$. pungens were collected. Both species, but T. pungens in higher numbers, were also collected attacking humans.

\section{Discussion}

We consider that the survey techniques employed in this work, using extensive sampling based on light traps, animal bait, and Malaise interception traps for nine months (interrupted after Covid-19 pandemy), were sufficient to ascertain the total diversity of tabanids living in Fernando de Noronha: only two common species.

Tabanus occidentalis is the most common species in the Neotropical Region, where it can be found all year long (Henriques \& Rafael 1999). In the continental mainland it is more abundant in the rainy season, as verified by Rafael \& Charlwood (1980) in the Occidental Amazon Basin and by Gorayeb (1993) in the Oriental Amazon Basin. One possible explanation for the positive relationship of $T$. occidentalis with precipitation is that humidity provides more viable habitats for oviposition, for instance moist soil. This species was more abundant at the Capim-Açú trail, a more preserved area. However, we have to consider that small bodies of water can be used as substrate for oviposition, considering that larvae have been found in water lettuce, Pistia stratiotes Linnaeus (Araceae) (Goodwin \& Murdoch 1974). This Araceae is common on the surface of the small ponds in Fernando de Noronha (Teixeira et al. 2003).

The density of $T$. pungens also correlated with precipitation, but negatively, in the continental mainland, where the specimens can be found throughout the year (Henriques \& Rafael 1999), they are more frequently collected in the drier months, and in open area as verified by Rafael (1982) in the Occidental Amazon Basin; and by Gorayeb (1993) in the Oriental Amazon Basin.

Despite the few numbers of T. pungens collected (six specimens) using interception traps, we collected 40 specimens (more than all other traps together during nine months that collected) near the Xaréu pond, with one small interception trap left in the field for only eight days. A possible explanation for this is the great density of water lettuce on the pond, one of the substrates already recorded for the larvae of this species (Goodwin \& Murdoch 1974). This shows that horse fly collecting must include as many different habitats as possible.

We collected some smaller specimens of $T$. occidentalis with some color variation, the smaller specimens being paler. The paler, smaller specimens have been treated by taxonomists as a "variety" of $T$. occidentalis. However, because of the similar morphology, we consider all specimens conspecific and follow the classification of Coscarón \& Papavero (2009), who considered all varieties as synonyms of T. occidentalis.

The tabanid fauna of the Fernando de Noronha is entirely derived from South America. It is opportune to consider that these two species are morphologically identical with mainland specimens, suggesting they are conspecific. Both species occur in the Brazilian Northeast, from which they most likely colonized Fernando de Noronha.

It is uncertain whether these species have been brought to Fernando de Noronha by man or wheather it was a natural dispersal. Although natural dispersion seems less likely, it should not be discarded. Tabanids are good fliers and movement through air is one probable means of dispersion. However, no Tabanus species has been documented breaking a distance of $360 \mathrm{~km}$ from the continent. Furthermore, these species are not found in the Greater Antilles island, which is much closer to the continent. A passive dispersion via rafting on the vegetation or other flotsam appears unlikely. To disperse this way, these flies would have to tolerate salt very well. This is not the case of either species since their larvae have been found in moist soil and roots of the aquatic plant water lettuce on the continent. Another argument against the natural dispersion hypothesis is that the predominant oceanic and wind currents from the occidental african coast, which can facilite dispersal on the sea surface and air, are counterclockwise, carrying marine floating debris from coastal Africa (Ivar do Sul et al. 2009). We think that the tabanid fauna of Fernando de Noronha has most likely been imported by humans and is now widespread. There has been active commerce between the continent and Fernando de Noronha over the years, which most likely has facilitated the transport of both species as immatures (eggs, larvae or pupae) or as adults. It is possible that larvae were transported in ships or planes in roots or leaves of plants, or adult female specimens were trapped in one or both these means of transport. About 300 plant species have been introduced to Fernando de Noronha (Teixeira et al. 2003). Cargo ships are not inspected to control the introduction of exotic species.

Larvae of T. occidentalis and T. pungens were taken from moist soil, usually in the vicinity of the roots of grasses and from water lettuce (Goodwin \& Murdoch 1974) and these could be the substrate where both species were transported when introduced in the archipelago. Water lettuce, Pistia stratiotes L. (Araceae) is dense on surface of the Xaréu pond and in other smaller ponds of the main island. The large numbers of T. pungens collected in the Xaréu pond, in only eight days, in the end of the rainy season, using small Malaise interception trap, is indicative that larvae are growing in the roots of this aquatic plant. No effort was made to find the larvae in Fernando de Noronha.

Tabanids are nuisance because of their painful and irritating persistent biting behavior, and blood ingestion. Cattle and horses suffer the most from constant annoyance and most animals react, as cow and horses, to the biting of the females by trying to dislodge them using the head, the tail, shaking the muscles or stamping the feet. Even when dislodged, the flies usually persist on the same animal or go on to a neighbor. The interrupted biting is likely a cause of direct transfer of blood-inhabiting pathogenic organisms among animals. According to Baldacchino et al. (2014) tabanids are 20-20,000 times more efficient mechanical vectors than other biting insects because the females can retain a large amount of blood $(7-15 \mathrm{~nL})$ in their mouthparts. For this reason they are implicated as vectors of the following diseases around the world: anaplasmosis, anthrax, equine encephalitis, equine infectious anemia, loiasis, mansonelosis, surra and tularemia (Rafael \& Henriques 2011, Baldacchino et al. 2014).

The high populational density of tabanids have an economic impact on tourism activities in the main island. They pester the tourists and their 
bite is quite painful. Additionally, cows and horses may suffer severely from heavy attacks of tabanids lowering milk production and impairing weight gain. Furthermore, during the rainy season when tabanid population densities are high, transmission of pathogens is facilitated.

Little is known about the potential transmission of pathogenic agents and parity by $T$. occidentalis and T. pungens. Unfortunately we did not collect during the three wetter months (March, April and May), which may hold more epidemiological importance because the density of tabanids is predicted to be higher.

If proved that both species are growing in the water lettuce, removal of this introduced aquatic plant from the ponds in Fernando de Noronha may be sufficient to control the density of the tabanid population in the archipelago.

Recently a horse fly species was detected attacking a lizard in Pará (Gorayeb \& Campos 2018). This record deserves attention because lizards are a reservoir of Salmonella, a bacterium with zoonotic potential that may represent a risk to children, elders and immunosuppressed people (Michelleti et al. 2020). The introduced teju lizard, Salvator merianae Duméril \& Bibron is abundant in Fernando de Noronha and a potential tabanid host.

Fernando de Noronha's native species have been impacted by the arrival of several exotic and invasive species, for instance domestic cats, dogs, brown and black rats, teju lizards, cattle egret (Michelleti et al. 2020), cows, horses and goats. Moreover, several zoonotic diseases, like salmonellosis and toxoplasmosis, have been linked to some of these invasive species (Michelleti et al. 2020) and this pathogens can be transmitted by T. occidentalis, as shown by Luz-Alves et al. (2007) in the North of Pará.

Our analysis focused mainly on elucidating the seasonality, density and population dynamics of $T$. occidentalis and T. pungens. These tabanids are hematophagous species harming the tourist industry, the main economic activity of Fernando de Noronha.

The tabanids of Fernando de Noronha might be able to transmit blood pathogens, thereby bringing health risks. Adult emergence of T. occidentalis occurs throughout the year with predictable peaks of abundance in the rainy season, mainly March to June; this leads to short but extremely high periods of tabanid activity and as a result tabanids can have drastic impacts. Tabanid density must be monitored throughout the year since they are also mechanical vectors of pathogenic agents.

\section{Acknowledgements}

We thank the staff at the Parque Nacional Marinho Fernando de Noronha, Ricardo Araújo, Viviane Vilella and Carolina Fonseca for administrative help; Autarquia Territorial do Distrito Estadual de Fernando de Noronha (ATDEFN), for granting us access to administrative facilities; and Layane Carvalho de Castro for field support; the Instituto Nacional de Pesquisas da Amazônia (INPA), for research support. To the Fundação de Amparo à Pesquisa do Estado do Amazonas (FAPEAM) and Conselho Nacional de Pesquisas (CNPq), for financial support Edital 001/2015 - CNPq/MCTI/FAPs/PROTAX, CNPq (process number 440.423/2015-5); CNPq for a research grant through Edital Universal 01/2016 - MCTI/CNPq (process number 405.630/2016-6) and for research fellowships to J.A.R. (process number 300019/2017-3); Coordenação de Aperfeiçoamento de Pessoal de Nível Superior (CAPES) for the student scholarships and post-doctoral fellowships; Instituto Chico Mendes de Conservação da Biodiversidade (ICMBio) for the Collecting License number 62.821.

\section{Author Contributions}

José Albertino Rafael: Contribution in the concept of the study; data collection; identification of the species; data analysis and interpretation; manuscript preparation.

Dayse Willkenia Almeida Marques: Contribution in the concept and design of the study; contribution to critical revision; manuscript preparation; preparation of the figures.

Alberto Moreira Silva-Neto: Contribution to data analysis and interpretation; manuscript preparation; contribution to critical revision, adding intellectual content.

Francisco Limeira-de-Oliveira: Contribution in the concept of the study; data collection; identification of the species; manuscript preparation; contribution to critical revision, adding intellectual content.

\section{Conflicts of Interest}

The authors declare that they have no conflict of interest related to the publication of this manuscript.

\section{References}

ALVARENGA, M. 1962. A entomofauna do arquipélago Fernando de Noronha, Brasil. Arq Mus Nac 52: 21-26.

BALDACCHINO. F., DESQUENES, M., MIHOC, S., FOIL, L.D., DUVALLET, G. \& JITTAPALAPONG, S. 2014. Tabanids: Neglected subjects of research, but important vectors of disease agents. Infect Genet Evol 28: 596-615. http://dx.doi.org/10.1016/j. meegid.2014.03.029

BARCELLOS, R.L., LINS, S.R.R.M., COELHO-JÚNIOR, C., TRAVASSOS, P.E.P.F. \& CAMARGO, P.B. de. 2015. Sistema sedimentar do Sueste: Caracterização morfossedimentar e geoquímica sazonal. Mar de fora, Fernando de Noronha (PE). Anais I Encontro de Pesquisa de Fernando de Noronha, São Pedro e São Paulo e Atol das Rocas, pp 98-101.

CARMO, R.F.R. \& VASCONCELOS, S.D. 2014. First record of the blow fly Chrysomya megacephala (Diptera: Calliphoridae) on a southern Atlantic island: implications for disease transmission in a protected environment. J Vector Ecol 39(1): 228-230. https://doi.org/10.1111/j.19487134.2014.12093.x

CORDEIRO, M.T., FREEZE, E., SCHATZMAYIR, H. \& NOGUEIRA, R.M.R. 2008. Vinte anos de evolução da dengue no Estado de Pernambuco. Ed. Universitária da UFPE, Recife, $225 \mathrm{pp}$.

COSCARÓN, S., PAPAVERO, N. 2009. Catalogue of Neotropical Diptera. Tabanidae. Neotropical Diptera 16: 1-199.

COURI, M.S., BARROS, G.P.S. \& ORSINI, M.P. 2008. Dipterofauna do arquipélago de Fernando de Noronha (Pernambuco, Brasil). Rev Bras Entomol 52(4): 588-590. https://doi.org/10.1590/S008556262008000400007

FREITAS, G.C.C., BRESCOVIT, A.D. \& VASCONCELOS, S.D. 2013. Spider diversity on the oceanic island of Fernando de Noronha, Brazil, and implications for species conservation. J Insect Sci 13 (148): 1-16. https:// doi.org/10.1673/031.013.14801

GOODWIN, J.T. \& MURDOCH, W.P. 1974. A study of some immature Neotropical Tabanidae (Diptera). Ann Entomol Soc Am 67(1): 85-133.

GORAYEB, I.S. 1993. Tabanidae (Diptera) da Amazônia. XI - sazonalidade das espécies da Amazônia Oriental e correlação com fatores climáticos. Bol Mus Para Emílio Goeldi, Zoo 9(2): 241-281. 
GORAYEB, I.S. \& CAMPOS, C.E.C. 2018. Tabanidae (Diptera) of the Amazon. XXII. First record of horse flies attacking golden tegu, Tupinambis teguixin Linnaeus 1758 (Reptilia: Squamata: Teiidae). Bol Mus Para Emílio Goeldi, Ciênc Nat 13(1): 157-160

GRESSITT, J.L. \& GRESSITT, M.K. 1962. An improved Malaise trap. Pacific Insects 4(1): 87-90.

HENRIQUES, A.L. \& RAFAEL, J.A. 1999. Tabanidae (Diptera) from Parque Nacional do Jaú, Amazonas, Brazil, with description of two new species of Diachlorus Osten Sacken. In: Burger JF (ed) Contributions to the knowledge of Diptera. A collection of articles on Diptera commemorating the life and work of Graham B. Fairchild. Associated Publishers, Florida. Memoirs on Entomology, International, Gainesvile 14, pp 195-222.

IBAMA. 2006. Parque Nacional Marinho de Fernando de Noronha. http://www. ibama.gov.br (last access in 10/07/2019).

IVAR DO SUL, J.A., SPENGLER, A. \& COSTA, M.C. 2009. Here, there and everywhere. Small plastic fragments and pellets on beaches of Fernando de Noronha (Equatorial Western Atlantic). Mar Pollut Bull. Recife, 58: 1229-1244.

KIRBY, W.F. 1890. Insecta, excepting Coleoptera. In: Ridley HN (ed) Notes on the Zoology of Fernando de Noronha. J Linn Soc Zool 20, pp 530-548. https://doi.org/10.1111/ j.1096-3642.1886.tb02243.x

LUZ-ALVES, W.C., GORAYEB, I.S., SILVA, J.C.L. \& LOUREIRO, E.C.B. 2007. Bacteria transported by horseflies (Diptera: Tabanidae) in the northeast of Pará State, Brazil. Bol Mus Para Emílio Goeldi, Ciênc Nat 2(3): 11-20.

MICHELETTI, T., FONSECA, F.S., MANGINI, P.R., SERAFINI, P.P., KRUL, R., MELLO, T.J., FREITAS, M.G., DIAS, R.A., SILVA, J.C.R., MARVULO, M.F.V., ARAUJO, R., GASPAROTTO, P.O., ABRAHÃO, C.R., REBOUÇAS, R., TOLEDO, L.P., SIQUEIRA, P.G.S.C., DUARTE, H.O., MOURA, M.J.C., FERNANDES-SANTOS, R.C. \& RUSSEL, J.C. 2020. Chapter 3. Terrestrial invasive species on Fernando de Noronha archipelago: what we know and the way forward. In: Londe V (ed) Invasive species, ecology, impacts, and potential uses. Nova Science Publisher, New York, pp 51-94.

OLIVEIRA, G.F., MELO, K.P.S., GARCIA, A.C.L. \& ROHDE, C. 2009. First record of Zaprionus indianus (Diptera, Drosophilidae) in Fernando de Noronha, an Oceanic Island of Pernambuco State, Brazil. Drosoph Inf Serv 92: 18-20.

OLIVEIRA, G.F., GARCIA, A.C.L. \& ROHDE, C. 2010. Flutuação populacional das espécies de Drosophilidae na Ilha de Fernando de Noronha, Pernambuco/ Brasil. In: Resumos do $56^{\circ}$ Congresso Brasileiro de Genética, Guarujá, São Paulo. p. 289.
RAFAEL, J.A. 1982. Ocorrência sazonal e abundância relativa de Tabanidae (Diptera) no Campus Universitário, Manaus, Amazonas. Acta Amaz 12: 225-229.

RAFAEL, J.A. \& CHARLWOOD, J.D. 1980. Idade fisiológica, variação sazonal e periodicidade diurna de quatro populações de Tabanidae (Diptera) no campus universitário, Manaus. Brasil. Acta Amaz 10(4): 907-927.

RAFAEL, J.A. \& HENRIQUES, A.L. 2011. Tabanidae, Capítulo 9. In: Marcondes CB (ed.). Entomologia Médica e Veterinária. Segunda edição, São Paulo. Ed. Atheneu, pp. 175-188. ISBN 9788538801832.

RAFAEL, J.A., LIMEIRA-DE-OLIVEIRA, F., HUTCHINGS, R.W., MIRANDA, G.F.G., SILVA-NETO, A.M., SOMAVILLA, A., CAMARGO, A., ASENJO, A., PINTO, A.P., BELLO, A. DE M., DALMORRA, C., MELLO-PATIU, C.A., CARVALHO, C.J.B. DE, TAKIYA, D.M., PARIZOTTO, D.R., MARQUES, D.W.A., CAVALHEIRO, D. DE O., MENDES, D.M.M., ZEPPELINI, D., CARNEIRO, E., LIMA, E.F.B., LIMA, E.C.A. DE, GODOI, F.S.P. DE, PESSOA, F.A.C., VAZ-DE-MELLO, F.Z., SOSADUQUE, F.J., FERNANDES, I.O., SILVA-JÚNIOR, J.O., GOMES, L.R.P., MONNÉ, M.L., CASTRO, M.C.M. DE, SILVA, M.P.G, DA, COURI, M.S., GOTTSCHALK, M.S., SOARES, M.M.M., MONNÉ, M.A., RAFAEL, M.S., CASAGRANDE, M.M., MIELKE, O.H.H., GROSSI, P.C., PINTO, P.J.C., BARTHOLOMAY, P.R., SOBRAL, R., HELEODORO, R.A., MACHADO, R.J.P., CORRÊA, R.C., HUTCHINGS, R.S.G., ALE-ROCHA, R., SANTOS, S.D. DOS, LIMA, S.P. DE, MAHLMANN, T., SILVA, V.C. \& FERNANDES, D.R.R. 2020. Insect (Hexapoda) diversity in the oceanic archipelago of Fernando de Noronha, Brazil: updated taxonomic checklist and new records. Rev Bras Entomol 64(3): e20200052. https:// doi.org/10.1590/1806-9665-rbent-2020-0052

R CORE TEAM. 2020. R: A Language and Environment for Statistical Computing. R Foundation for Statistical Computing, Vienna.

SHORTHOUSE, D.P. 2010. SimpleMappr, an online tool to produce publicationquality point maps. https://www.simplemappr.net (last access in 15/08/2019)

TEIXEIRA, W., CORDANI, U.G., MENOR, E.A., TEIXEIRA, M.G., LINSKER, R. et al. 2003. Arquipélago Fernando de Noronha: o paraíso do vulcão. São Paulo: Terra Virgem Ed., 167 pp.

TOWNES, H. 1972. A light-weight Malaise trap. Ent News 83: 239-247.
Received: 04/03/2021

Revised: 11/05/2021

Accepted: 13/06/2021

Published online: 19/07/2021 